\title{
Growth Pattern of Early and Late Breast Fed Preterm (30-35 Weeks' Gestation) Neonates: A Hospital Based Study
}

\author{
TAHSINUL AMIN ${ }^{1}$, M A KAZAD CHOWDHURY², M MONIR HOSSAIN ${ }^{3}$, M MAHBUBUL HOQUE ${ }^{4}$
}

\begin{abstract}
Background: There is still controversy among the pediatricians regarding when and how to start enteral feeding in preterm neonates. However, early feeding with breast milk was presumed to be well-tolerated, cost-effective and promote growth better than late feeding. Objectives: To compare growth pattern, benefits and risks between early and late breast feeding in preterm (30-35 weeks' gestation) neonates. Methods: This was a randomized controlled trial. Total 100 preterm neonates were stratified into early feeding $(n=50)$ and late feeding $(n=50)$ groups. Early feeding was started on day 3 and late feeding on day 5 of life with expressed breast milk as $20 \mathrm{ml}$ $\mathrm{kg} /$ day by gavage feeding with daily increment $20 \mathrm{ml} / \mathrm{kg}$ till full enteral feeding. Growth was recorded by anthropometric measurements with accuracy and precision for first 3 months of life. Results: Early breast feeding was found to be significantly better than late breast feeding in duration to reach full feeding (13.08 days vs. 16.70 days), time to regain enrolment weight (10.87 days vs. 13.70 days), feed tolerance (78\% vs. $58 \%$ ), hospital stay (13.58 days vs. 16.82 days), mean weight (3773.62 $\pm 310.49 \mathrm{gm}$ vs. $3636.91 \pm 340.20 \mathrm{gm})$, linear growth $(53.64 \pm 2.26 \mathrm{~cm}$ vs. $52.62 \pm 2.04 \mathrm{~cm})$ and OFC growth ( $35.85 \pm 1.50 \mathrm{~cm}$ vs. $35.35 \pm 1.40 \mathrm{~cm})$ at 3 months of age. Conclusion: Early feeding with breast milk is well tolerated with less morbidity and promotes growth better than late feeding in preterm neonates.
\end{abstract}

Key words:Growth pattern, preterm, breast fed.

\section{Introduction}

Preterm infants require special attention and care due to physical immaturity and vulnerability to increased morbidity and mortality. Premature birth is not a normal event; it results from a disturbance of pregnancy at a time when the fetus should be growing rapidly, with all the body systems maturing rapidly and the brain developing at its fastest ${ }^{1}$. Preterm neonates are especially vulnerable because of premature delivery and low birth weight. Good nutrition is essential to promote accelerated growth and long term development ${ }^{2}$. Nutrients can be provided either parenterally or enterally but the aim in all infants is to use full enteral feeding as soon as it is safe to do $\mathrm{so}^{2}$. The process of enteral feeding e.g. sucking, swallowing, gastric emptying and small gut peristalsis is inefficient in the preterm baby ${ }^{3}$. Intestinal permeability is increased and results in increased macromolecular transport across the epithelium ${ }^{3}$. This may be relevant to the development of necrotizing enterocolitis (NEC) by allowing bacteria and antigen to penetrate the gut wall ${ }^{4}$.

In neonates, early feeding may improve lactase activity and pancreatic function but has its principal advantage in inducing maturation of motor function of the gut ${ }^{5}$. Early enteral feeding may promote growth and shorten the duration of parenteral nutrition and hospital stay without increasing the risk for $\mathrm{NEC}^{6}$. Early enteral feeding is associated with better endocrine adaptation, enhanced immune functions and gut motility ${ }^{7}$. Institutional practices may vary, in general, enteral feeding can be started in first 3 days of life with the objective of reaching full feeding in 2-- to 3 weeks $^{8}$. However, early enteral feeds may also cause feed

1. Resident Physician (Paediatrics), Shaheed Ziaur Rahman Medical College Hospital, Bogra, Bangladesh.

2. Professor \& Head of Division of Neonatology, Bangladesh Institute of Child Health \& Dhaka Shishu Hospital, Dhaka, Bangladesh.

3. Associate professor, Division of Neonatology, Bangladesh Institute of Child Health \& Dhaka Shishu Hospital, Dhaka, Bangladesh.

4. Assistant professor, Division of Neonatology, Bangladesh Institute of Child Health \& Dhaka Shishu Hospital, Dhaka, Bangladesh.

Correspondence: Dr. Tahsinul Amin 
intolerance, abdominal distention, apnea, vomiting or necrotizing enterocolitis ${ }^{9}$. Besides, late enteral feeding could diminish the functional adaptation of the gastrointestinal tract and results in feeding intolerance later followed by $\mathrm{NEC}^{10}$. This is the reason it is still debatable when and how to start enteral feeds in preterm LBW neonates. The general objective of the study was to find out the optimal timing to start enteral feeding in preterm neonates which would ensure their maximum growth and the specific objectives were to compare growth pattern (i.e. weight, length and head circumference) between early breast feeding and late breast feeding in preterm (30-35 weeks' gestation) neonates and to compare benefits and risks between early breast feeding and late breast feeding.

\section{Meterials and Methods}

This was a randomized controlled trial done in the Neonatal Special Care Unit of Dhaka Shishu Hospital, Dhaka, Bangladesh, from July 01, 2004 to October 31,2005 . The inclusion criteria were preterm neonates of 30-35 weeks' gestation, appropriate for gestational age (AGA) and $<72$ hours of age. The exclusion criteria were perinatal asphyxia, neonatal sepsis as confirmed by blood culture or clinical septicemia, major congenital anomaly, suspected necrotizing enterocolitis (NEC) e.g., GI bleeding, neonates on enteral feeding before admission and critically ill neonates. The sample size was 100 , stratified into early breast fed $(n=50)$ and late breast fed $(n=50)$ groups. Among the hospital admitted preterm (30-35 weeks' gestation) neonates, sample was selected by fulfilling the inclusion criteria and after obtaining informed written consent from the parents for enrolment in the study. Gestational age was estimated by new Ballard score. Sample subjects were assigned to either early breast feeding or late breast feeding group through randomization by lottery method of selection of cards labeled as early breast feeding or late breast feeding group in sealed opaque envelopes. The protocol of the study was approved by the thesis and dissertation committee of $\mathrm{BICH}$ and ethical review committee of Dhaka Shishu Hospital, Dhaka, Bangladesh.

\section{Feeding protocol}

Early feeding group includes preterm neonates feeding started on day 3 and late feeding group includes preterm neonates feeding started on day 5 of life ${ }^{11,12}$. Only breast milk was given as feeds. In both the groups, feeding was started with expressed breast milk as $20 \mathrm{ml} / \mathrm{kg} /$ day by nasogastric gavage feeding at 2 hourly intervals in addition to parenteral nutrition and daily increment was $20 \mathrm{ml} / \mathrm{kg}$ till maximum enteral feeds of $180 \mathrm{ml} / \mathrm{kg} /$ day were reached ${ }^{13,14}$. Before starting enteral feeds, a test feed was given with maternal breast milk; if the feed was tolerated, then oral intake was continued. However, if there were evidence of feeding intolerance e.g., the infant had $>30-50 \%$ gastric residue of the previous feed or gastric residual $>3 \mathrm{ml} / \mathrm{kg}$ body weight, apnea, bilious vomiting, GIT bleeding, paralytic ileus or NEC, then subsequent feeding was not given ${ }^{15}$. The color of the gastric residual volume (GRV) was assessed as clear, milk colored, green (bilious) or blood-stained (haemorrhagic).

NEC was defined as clinical signs e.g. an increase in abdominal girth $>2 \mathrm{~cm}$ between the feeds, bilious vomiting and fresh per rectal bleeding, with the presence of pneumatosis intestinalis on abdominal radiograph (Bell stage II) ${ }^{7}$. However, if there was mild or moderate abdominal distention i.e., $<2 \mathrm{~cm}$ increase between feeds and patient's clinical condition was stable, enteral feed was continued without any increment of feeds until abdominal distention was relieved. If gastric aspirate $<3 \mathrm{ml} / \mathrm{kg}$ body weight, then no further increase in feeds was made over the next 24 hours; however, if gastric aspirate was $>3 \mathrm{ml} / \mathrm{kg}$ body weight, severe abdominal distention i.e., an increase in abdominal girth $>2 \mathrm{~cm}$ between feeds, apnea, bilious vomiting or GIT bleeding, then feeding was discontinued temporarily for 24-48 hours. During this period the infant was investigated for sepsis and NEC (complete blood count, CRP, blood culture, abdominal $X$ ray, serum electrolytes, stool for blood) ${ }^{15}$. Sepsis was defined as clinical signs consistent with systemic infection plus at least one positive blood culture $^{11}$. If the investigations turned out to be negative, then feeds were restarted at half the volume the infant was receiving at the time of discontinuation of feeds. ${ }^{15}$ If the infant was diagnosed to have NEC, then the management was as per the standard management protocol for NEC ${ }^{10}$.

During the whole study, at every time of feeding it was checked whether the previous feed was tolerated or not. Bolus feedings were given through nasogastric tube every 2 hours for 20 minutes by the action of gravity; as the infants became more accustomed to enteral feeding with improvement of coordinated sucking, swallowing and breathing, gradually feeds were given by spoon or cup and finally successful breast feeding. A total daily fluid intake of $180 \mathrm{ml} / \mathrm{kg}$ was maintained by concomitant reduction in parenteral 
nutrition. When enteral intake exceeded $150 \mathrm{ml} / \mathrm{kg} /$ day, parenteral nutrition was discontinued ${ }^{7}$. The maximum enteral feeds of $180 \mathrm{ml} / \mathrm{kg} /$ day was finally achieved $^{13}$. The criteria for hospital discharge were uniform among the study infants: satisfactory weight gain (i.e., weight gain 15-20 gm/day) while receiving full oral feeding, maintenance of thermal stability and resolution of acute medical conditions ${ }^{12}$.

Measurement of growth (i.e.,) weight, length and head circumference)

Regular anthropometric measurements were recorded. Weight was measured daily by an electronic weighing scale (Scale-Tronix Paediatric Scale, USA), which was accurate to $5 \mathrm{gm}$ and was calibrated before each measurement. Weighing was carried out with the baby nude and before feeding with accuracy and precision. Crown-heel length was measured weekly using a neonatometer (i.e. neonatal stadiometer) to the nearest 1 millimeter and head (i.e., occipito-frontal) circumference was measured weekly with an inelastic standard plastic measuring tape $(1 \mathrm{~cm}$ wide) to the nearest 1 millimeter. Crown-heel length was measured from the top of the head to the sole of the foot with the body lying supine. The head circumference is the maximum circumference around the head at the level of the point just above the glabella anteriorly and the occiput posteriorly ${ }^{16}$. All the measurements were carried out by a single observer at the same time every day; the values were measured three times and the mean value was recorded and it was double checked by another observer to ensure precision of the measurement. Follow up and growth monitoring were continued regularly at monthly intervals up to 3 months of age.

\section{Data analysis}

The data analyses were made with SPSS version 12.0 software (SPSS Inc., Chicago, USA). The results were reported as mean $( \pm S D)$ for early breast feeding and late breast feeding. Student's independent ' $t$ ' test was used for comparison between continuous variables.
Pearson chi-square test and Fisher's exact test were used for comparison between categorical variables. Fisher's exact test was used if frequencies for categorical variables were less than 5 . Pearson chisquare test was used for all other categorical variables. Statistical significance was set at 0.05 level of probability.

\section{Results}

Total 100 preterm (30-35 weeks' gestation) neonates were enrolled in the study, 50 each in early breast fed and late breast fed groups; 3 infants died in each group during hospitalization due to sepsis and NEC. Of the remaining infants, 8 infants in early breast fed and 10 infants in late breast fed group were lost in follow up. Finally, 39 infants in early breast fed and 37 infants in late breast fed group completed follow up till 3 months of age for growth monitoring. In the data analysis 18 infants, who were drop out in follow up, were excluded from analysis of growth. Early breast fed and late breast fed groups were comparable in gestational age, weight on admission and sex, $(p>0.05)$ (Table-I).

Feed was tolerated better in early feeding than late feeding ( $78 \%$ vs. $58 \%, p<0.05)$ and feed was withheld less in early feeding compared to late feeding (10\% vs. $26 \%, p<0.05$ ) (Table-II). There was a significant difference between early feeding and late feeding in caloric intake, time to regain enrolment weight, duration to reach full enteral feeding and hospital stay $(p<0.05)$ (Table-III).

There was no significant difference between early feeding and late feeding in weight at enrolment, 1 month and 2 months but a significant difference was found at 3 months $(p<0.05)$ (Table-IV). Similarly, there was no significant difference in length at enrolment but a significant difference was found in linear growth at 1 month, 2 months and 3 months $(p<0.05)$ (Table$v)$. In OFC growth there was no significant difference at enrolment, 1 month, 2 months and 3 months ( $p$ > 0.05) (Table-VI).

Table-I

Particulars of the studied babies

\begin{tabular}{lccc}
\hline Parameter & $\begin{array}{c}\text { Group-I } \\
(\text { Early breast fed }) \\
(\mathrm{n}=50)\end{array}$ & $\begin{array}{c}\text { Group-II } \\
(\text { Late breast fed }) \\
(\mathrm{n}=50)\end{array}$ & p value \\
& $32.5 \pm 1.8$ & $32.3 \pm 1.7$ & \\
\hline Gestational age (weeks) & $1665.9 \pm 255.3$ & $1649.6 \pm 267.7$ & 0.655 \\
Weight on admission (gm) & $28(56)$ & $24(48)$ & 0.756 \\
Male $\mathrm{n}(\%)$ & $22(44)$ & $26(52)$ & 0.543 \\
Female $\mathrm{n}(\%)$ & & & \\
\hline
\end{tabular}


Table-II

Feeding outcome

\begin{tabular}{lccc}
\hline $\begin{array}{l}\text { Events \& Problems related to } \\
\text { Breast feeding }\end{array}$ & $\begin{array}{c}\text { Group-I } \\
\text { (Early breast fed) } \\
\mathrm{n}(\%)\end{array}$ & $\begin{array}{c}\text { Group-II } \\
\text { (Late breast fed) } \\
\mathrm{n}(\%)\end{array}$ & $\begin{array}{c}\mathrm{p} \\
\text { value }\end{array}$ \\
\hline Feed tolerance & $39(78)$ & $29(58)$ & 0.032 \\
Feed intolerance & $11(22)$ & $21(42)$ & 0.498 \\
Abdominal distention & $13(26)$ & $18(36)$ & \\
Abdominal distention \& bleeding & $2(4)$ & $3(6)$ & \\
Necrotizing enterocolitis & $1(2)$ & $2(4)$ & 0.037 \\
Apnea & $3(6)$ & $5(10)$ & \\
Feeding not withheld & $45(90)$ & $37(74)$ & $13(26)$ \\
Feeding withheld & $5(10)$ & & \\
\hline
\end{tabular}

Table-III

Clinical outcome

\begin{tabular}{lccc}
\hline $\begin{array}{l}\text { Parameter } \\
\text { (Mean } \pm \text { SD) }\end{array}$ & $\begin{array}{c}\text { Group-I } \\
\text { (Early breast fed) } \\
\text { Mean } \pm \text { SD }\end{array}$ & $\begin{array}{c}\text { Group-II } \\
\text { (Late breast fed) } \\
\text { Mean } \pm \text { SD }\end{array}$ & p value \\
\hline Caloric intake (kcal/kg/day) & $87.3 \pm 1.1$ & $81.1 \pm 1.0$ & $<0.001$ \\
Days to regain enrolment weight & $10.9 \pm 2.6$ & $13.7 \pm 2.7$ & $<0.001$ \\
Days to reach full feed & $13.1 \pm 3.1$ & $16.7 \pm 3.3$ & $<0.001$ \\
Hospital stay (days) & $13.6 \pm 3.4$ & $16.8 \pm 4.2$ & $<0.001$ \\
\hline
\end{tabular}

Table-IV

Weight gain in first 3 months of life

\begin{tabular}{|c|c|c|c|}
\hline $\begin{array}{l}\text { Time of measurement } \\
\text { of weight }\end{array}$ & $\begin{array}{c}\text { Group-I } \\
\text { (Early breast fed) } \\
(\mathrm{n}=39) \\
\text { Weight }(\mathrm{gm}) \\
\text { (Mean } \pm \text { S.D.) }\end{array}$ & $\begin{array}{c}\text { Group-II } \\
\text { (Late breast fed) } \\
(n=37) \\
\text { Weight }(g m) \\
\text { (Mean } \pm \text { S.D.) }\end{array}$ & $p$ value \\
\hline At enrolment & $1659.3 \pm 258.3$ & $1645.9 \pm 269.0$ & 0.800 \\
\hline At the end of 1 month & $2194.5 \pm 289.6$ & $2128.8 \pm 317.0$ & 0.297 \\
\hline At the end of 2 months & $2947.3 \pm 285.0$ & $2859.6 \pm 320.4$ & 0.164 \\
\hline At the end of 3 months & $3773.6 \pm 310.5$ & $3636.9 \pm 340.2$ & 0.045 \\
\hline
\end{tabular}

Tabl-V

Linear growth in first 3 months of life

\begin{tabular}{lccc}
\hline $\begin{array}{l}\text { Time of measurement } \\
\text { of length }\end{array}$ & $\begin{array}{c}\text { Group- I } \\
\left(\begin{array}{c}\text { Early breast fed }) \\
(\mathrm{n}=39)\end{array}\right. \\
\text { Length }(\mathrm{cm}) \\
(\text { Mean } \pm \text { S.D. })\end{array}$ & $\begin{array}{c}\text { Group- II } \\
(\text { Late breast fed }) \\
(\mathrm{n}=37) \\
\text { Length }(\mathrm{cm})\end{array}$ & p value \\
& $43.1 \pm 2.0$ & $42.5 \pm 1.9$ & \\
\hline At enrolment & $46.6 \pm 2.1$ & $45.7 \pm 2.0$ & 0.159 \\
At the end of 1 month & $50.2 \pm 2.1$ & $49.2 \pm 2.0$ & 0.041 \\
At the end of 2 months & $53.6 \pm 2.3$ & $52.6 \pm 2.0$ & 0.022 \\
At the end of 3 months & & 0.024 \\
\hline
\end{tabular}


Table-VI

OFC growth in first 3 months of life

\begin{tabular}{lccc}
\hline $\begin{array}{l}\text { Time of measurement } \\
\text { of OFC }\end{array}$ & $\begin{array}{c}\text { Group-I } \\
\left(\begin{array}{c}\text { Early breast fed }) \\
(\mathrm{n}=39) \\
\text { OFC }(\mathrm{cm}) \\
(\text { Mean } \pm \text { S.D. })\end{array}\right.\end{array}$ & $\begin{array}{c}\text { Group-II } \\
(\text { Late breast fed }) \\
(\mathrm{n}=37) \\
\text { OFC }(\mathrm{cm}) \\
(\text { Mean } \pm \text { S.D. })\end{array}$ & p value \\
\hline At enrolment & $29.9 \pm 1.5$ & $29.8 \pm 1.4$ & 0.886 \\
At the end of 1 month & $31.9 \pm 1.5$ & $31.7 \pm 1.3$ & 0.442 \\
At the end of 2 months & $33.9 \pm 1.5$ & $33.6 \pm 1.4$ & 0.322 \\
At the end of 3 months & $35.9 \pm 1.5$ & $35.4 \pm 1.4$ & 0.099 \\
\hline
\end{tabular}

OFC= occipito-frontal circumference

\section{Discussion}

Early enteral feeding with breast milk is presumed to be well-tolerated, cost-effective and promotes growth better than late enteral feeding ${ }^{6}$. In this randomized controlled trial, both the early breast feeding and late breast feeding groups were comparable in gestational age, weight on admission and sex. Caloric intake was significantly higher in early feeding than late feeding $\{87.32( \pm 1.11) \mathrm{kcal} / \mathrm{kg} /$ day vs. $81.10( \pm 1.01) \mathrm{kcal} / \mathrm{kg} /$ day, $p<0.05\}$ for first 15 days of life. This is consistent with some previous studies ${ }^{15,17}$. Early feeding took significantly fewer days to regain enrolment weight than late feeding $\{10.87( \pm 2.55)$ days vs. $13.70( \pm 2.66)$ days, $p<0.05\}$. This is also consistent with some previous studies ${ }^{12,18}$. Early feeding also took significantly shorter duration to reach full enteral feeding than late feeding $\{13.08$ ( \pm 3.05 ) days vs. 16.70 $( \pm 3.27)$ days, $p<0.05\}$, which is also consistent with the Berseth ${ }^{19}$ study. Feeding was significantly tolerated better in early feeding than late feeding group (78\% vs. $58 \%, p<0.05)$. This is also consistent with the previous study ${ }^{15}$. Feed was withheld significantly more in late feeding than in early feeding ( $26 \%$ vs. $10 \%, p<0.05$ ); this is also consistent with the Wilson et $\mathrm{al}^{12}$ trial. Frequency of complications of feeding e.g., abdominal distention, gastro-intestinal bleeding, NEC (i.e., necrotizing enterocolitis) and apnea was more in late feeding than early feeding group having no significant difference in this regard. Previous studies ${ }^{10,20}$ also showed lower incidence of NEC in early feeding than late feeding. Early feeding had significantly shorter duration of hospital stay than late feeding $\{13.58( \pm 3.37)$ days vs. $16.82( \pm 4.15)$ days, $p$ $<0.05\}$. This is also consistent with some other studies $^{11,12}$. In this study, growth pattern of early breast feeding and late breast feeding were compared. At enrolment both the early feeding and late feeding groups were comparable in weight, length and OFC. Eventually growth (i.e., weight at 3 months and length at 1 month, 2 months and 3 months) was significantly higher in early breast feeding than late breast feeding, which is consistent with the Wilson et al ${ }^{12}$ study.

\section{Conclusion}

Early initiation of enteral feeding with breast milk in the preterm LBW neonates was found significantly better than late feeding in promotion of growth, feed tolerance, hospital stay, morbidity, etc. Our recommendation through this study is that breast feeding should be started early in this population provided the infants are not otherwise sick which contraindicates enteral feeding. A large multi-center long term study would further validate the benefits of early feeding with breast milk than late feeding.

\section{References}

1. Marlow N. Neurocognitive outcome after very preterm birth. Arch Dis Child Fetal Neonatal Ed 2004; 89: F224-F28.

2. Slagle TA, Gross SJ. Effect of early low-volume enteral substrate on subsequent feeding tolerance in very low birth weight infants. J Pediatr 1988; 113: 526-31.

3. Gomella TL, Cunningham MD, Eyal FG, Zenk $\mathrm{KE}$, editors. Neonatology: Management, Procedures, On-Call Problems, Diseases and Drugs. 5th ed. USA: Mc Graw Hill; 2004. P. 77101.

4. Patole SK, Klerk ND. Impact of standardized feeding regimens on incidence of neonatal 
necrotizing enterocolitis: a systematic review and meta-analysis of observational studies. Arch Dis Child Fetal Neonatal Ed 2005; 90: F147-F51.

5. Kennedy KA, Tyson JE, Chamnanvanikij S. Early versus delayed initiation of progressive enteral feedings for parenterally fed low birth weight or preterm infants [online]. 1999 [cited 2004 August 5]. Available from: URL: http://www.nichd.nih.gov/ cochrane/kennedy2/kennedy.htm

6. Lucas A, Morley R, Cole TJ, Gore SM. A randomised multicentre study of human milk versus formula and later development in preterm infants. Arch Dis Child 1994; 70: 141-46.

7. McGuire W, Anthony MY. Donor human milk versus formula for preventing necrotizing enterocolitis in preterm infants: systematic review. Arch Dis Child Fetal Neonatal Ed 2003; 88: 11-14.

8. Macdonald PD, Ross SRM, Grant L, Young D. Neonatal weight loss in breast and formula fed infants. Arch Dis Child Fetal Neonatal Ed 2003; 88: F472-F76.

9. Cooke RJ, Embleton ND. Feeding issues in preterm infants. Arch Dis Child Fetal Neonatal Ed 2000; 83: F215-F18.

10. LaGamma EF, Ostertag SG, Birenbaum H. Failure of delayed oral feedings to prevent necrotizing enterocolitis. AJDC 1985; 139: 385-89.

11. Ronnestad A, Abrahamsen TG, Medbo S. Lateonset septicemia in a Norwegian national cohort of extremely premature infants receiving very early full human milk feeding. Pediatrics 2005; 115: 269-76.

12. Wilson DC, Cairns $P$, Halliday $\mathrm{HL}$, Reid $\mathrm{M}$, McClure G, Dodge JA. Randomised controlled trial of an aggressive nutritional regimen in sick very low birth weight infants. Arch Dis Child 1997; 77: 4-11.

13. Schanler RJ, Shulman RJ, Lau C, Smith EB, Heitkemper MM. Feeding strategies for premature infants: randomized trial of gastrointestinal priming and tube-feeding method. Pediatrics 1999; 103: 434-39.

14. Fewtrell M, Lucas A. Feeding low-birth weight infants. In: Rennie JM, Roberton NRC, editors. Textbook of Neonatology. 3rd ed. Edinburgh: Churchill Livingstone 1999. P. 338-48.

15. Meetze WH, Valentine C, McGuigan JE, Conlon M, Sacks N, Neu J. Gastrointestinal priming prior to full enteral nutrition in very low birth weight infants. J Pediatr Gastroenterol Nutr 1992; 15: 163-70.

16. Huysman WA, Ridder MD, Bruin NC, et al. Growth and body composition in preterm infants with bronchopulmonary dysplasia. Arch Dis Child Fetal Neonatal Ed 2003; 88: F46-F51.

17. McClure RJ, Newell SJ. Randomised controlled study of clinical outcome following trophic feeding. Arch Dis Child Fetal Neonatal Ed 2000; 82: F29-F33.

18. Wu PYK, Teilmann P, Gabler M, Vaughan M, Metcoff J. Early versus late feeding of low birth weight neonates: effect on serum bilirubin, blood sugar, and responses to glucagon and epinephrine tolerance tests. Pediatrics 1967; 39: 733-39.

19. Berseth CL. Effect of early feeding on maturation of the preterm infant's small intestine. J Pediatr 1992; 120: 947-53.

20. Kamitsuka MD, Horton MK, Williams MA. The incidence of necrotizing enterocolitis after introducing standardized feeding schedules for infants between 1250 and 2500 grams and less than 35 weeks of gestation. Pediatrics 2000; 105: 379-84. 